\title{
The Danish hearing in noise test
}

\author{
Nielsen, Jens Bo; Dau, Torsten
}

Published in:

International Journal of Audiology

Link to article, DOI:

10.3109/14992027.2010.524254

Publication date:

2010

Document Version

Early version, also known as pre-print

Link back to DTU Orbit

Citation (APA):

Nielsen, J. B., \& Dau, T. (2010). The Danish hearing in noise test. International Journal of Audiology, 50(3), 202208. https://doi.org/10.3109/14992027.2010.524254

\section{General rights}

Copyright and moral rights for the publications made accessible in the public portal are retained by the authors and/or other copyright owners and it is a condition of accessing publications that users recognise and abide by the legal requirements associated with these rights.

- Users may download and print one copy of any publication from the public portal for the purpose of private study or research.

- You may not further distribute the material or use it for any profit-making activity or commercial gain

- You may freely distribute the URL identifying the publication in the public portal

If you believe that this document breaches copyright please contact us providing details, and we will remove access to the work immediately and investigate your claim 


\title{
Original Article
}

\section{The Danish hearing in noise test}

\author{
JENS BO NIELSEN \& TORSTEN DAU \\ Centre for Applied Hearing Research, Department of Electrical Engineering, Technical University of Denmark, Lyngby, Denmark
}

\begin{abstract}
Objective: A Danish version of the hearing in noise test (HINT) has been developed and evaluated in normal-hearing (NH) and hearing-impaired (HI) listeners. The speech material originated from Nielsen \& Dau (2009) where a sentence-based intelligibility equalization method was presented. Design: In the present study, the speech material was evaluated for naturalness and a subset of sentences selected. The new sentence lists were validated, and after three weeks retested. An additional experiment investigated how recollection of sentences affected the listeners' performance. Study sample: $16 \mathrm{NH}$ and $16 \mathrm{HI}$ listeners participated in the validation and retest. Twelve HI listeners participated in the experiment on recollection. Results: The average speech recognition threshold in noise $\left(\mathrm{SRT}_{\mathrm{N}}\right)$ for the $\mathrm{NH}$ listeners was $-2.52 \mathrm{~dB}$, with an overall standard deviation of $0.87 \mathrm{~dB}$. The within-subject standard deviation was similar for the NH and the HI listeners. In the retest, the $\mathrm{SRT}_{\mathrm{N}}$ decreased by $0.4 \mathrm{~dB}$ in both groups. Conclusions: The Danish HINT consists of 10 test lists and three practice lists each containing 20 sentences. The validation results are comparable to those of other versions of HINT. The test seems equally reliable for NH and HI listeners. After three weeks, reliable results can be obtained when sentence lists are reused with the same listeners.
\end{abstract}

\section{Sumario}

Objetivo: Se ha desarrollado una versión danesa del HINT en sujetos normoyentes (NH) y en hipoacúsicos (HI). Se presentó el material del habla originado por Nielsen \& Dau (2009) en donde el método de ecualización fue basado en la inteligibilidad de una oración. Diseño: Se evaluó la naturalidad del material del habla y un subgrupo seleccionado de oraciones. Las nuevas listas de oraciones se validaron y después de tres semanas se re-examinaron. Un experimento adicional investigó cómo afectaba el desempeño de los oyentes la recolección de las oraciones. Muestra: $16 \mathrm{NH}$ y $16 \mathrm{HI}$ participaron en la validación y la re-examinación. Doce HI participaron en la recolección del experimento. Resultados: El umbral promedio del reconocimiento del habla en ruido ( $\mathrm{SRT}_{\mathrm{N}}$ ) para los participantes $\mathrm{NH}$ fue $-2.52 \mathrm{~dB}$ con un desviación estándar general de 0.87 dB. La desviación estándar intra-sujeto fue similar para los participantes NH y los HI. En la re-examinación el SRTN disminuyó en 0.4dB en ambos grupos. Conclusiones: El HINT danés consta de 10 listas y tres listas de práctica; cada una contiene 20 oraciones. La validación de resultados es comparable a aquella de otra versión de HINT. La prueba parece ser igualmente confiable para personas NH que para HI. Después de tres semanas los SRTN disminuyeron muy ligeramente cuando las listas de oraciones fueron usadas en los mismos oyentes.

Key Words: Speech intelligibility; Speech perception; HINT; Danish

Nielsen \& Dau (2009) developed a speech intelligibility test in Danish, the conversational language understanding evaluation (CLUE), based on the principles of the original hearing in noise test (HINT; Nilsson et al, 1994). The CLUE test consists of 18 phonetically balanced test lists and seven practice lists. Each list contains 10 sentences. After its completion, the CLUE test was presented to the Danish hearing aid manufacturers Oticon, GN Resound, and Widex, and one of the companies conducted an extensive internal evaluation of the test. The evaluation acknowledged that the validation results for CLUE were comparable to those of the original HINT and to those of other language versions of the test, e.g. the Canadian-French version (Vaillancourt et al, 2005), the Cantonese version (Wong \& Soli, 2005), and the Swedish version (Hällgren et al, 2006). However, the evaluation also indicated some concerns regarding (1) the speech material, (2) the choice of talker, and (3) the scoring rules, as outlined in the following.
1) The CLUE sentences were based on written materials like newspapers and magazines and fulfilled a set of criteria (Nielsen \& Dau, 2009), but these criteria did not include an explicit requirement for simplicity in wording or contents. In contrast, typical HINT sentences are based on text materials that can be understood by 6-7 year-old children. The evaluation considered several sentences in the CLUE material as being unnatural or having a higher level of abstraction than typical for HINT sentences. Some sentences have inversion (reversed word order) and some verbs are in passive form. Furthermore, the evaluation considered some words and expressions to be 'old-fashioned'.

2) The evaluation pointed out that the talker's voice quality varies over time and that his pronunciation is 'remarkable' partly because of tension. The pronunciation of some of the sentences was considered less clear than that of others and the speed of

Correspondence: Jens Bo Nielsen, Centre for Applied Hearing Research, Ørsteds Plads 352, DK-2800 Kgs. Lyngby, Denmark. E-mail: jbn@elektro.dtu.dk 


\begin{tabular}{|ll|}
\hline \multicolumn{2}{|l|}{ Abbreviations } \\
CLUE & $\begin{array}{l}\text { Conversational language understanding } \\
\text { evaluation }\end{array}$ \\
$\mathrm{HI}$ & Hearing-impaired \\
$\mathrm{HINT}$ & Hearing in noise test \\
$\mathrm{IEC}$ & International Electrotechnical Commission \\
& (Geneva) \\
$\mathrm{NH}$ & Normal-hearing \\
$\mathrm{SNR}$ & Signal-to-noise ratio \\
$\mathrm{SRT}_{\mathrm{N}}$ & Speech recognition threshold in noise \\
$\mathrm{SRT}_{\mathrm{Q}}$ & Speech recognition threshold in quiet \\
\hline
\end{tabular}

speech was perceived as slightly varying. It was argued that a more trained talker would be preferable in order to achieve a speech material as consistent and 'transparent' as possible.

3) The scoring rules for a sentence test determine when a listener's response is considered correct, and these rules typically permit minor response deviations from the actual sentence. The CLUE scoring rules permit both some general variations, e.g. a change of verb tense, and a few specific variations. In the evaluation, it was argued that the CLUE scoring rules might cause less consistent scoring than would be desirable, and a clarification of the rules was recommended.

A project was established with the objective of creating a new speech intelligibility test that was based on CLUE but took the abovementioned concerns into consideration. The test was to be validated for both normal-hearing $(\mathrm{NH})$ and hearing-impaired (HI) listeners, since homogeneous test results for $\mathrm{NH}$ listeners do not necessarily imply homogeneous results for HI listeners (McArdle \& Wilson, 2006). In addition, the goal was to create a test that corresponds to the current HINT standard (Bio-logic Systems Corp., 2005), such that it can be referenced as 'the Danish HINT'. The standard demands test lists with 20 sentences per list, which is twice as many as in the original HINT and in CLUE. It was assumed that an improved speech material for the new test could be achieved by exchanging some of the CLUE test sentences with sentences from the CLUE practice lists.

As part of the project, effects of learning, typically involved in a sentence test, were investigated. Here, learning is considered as the combination of two separate effects; one related to 'practice' and one related to 'memory'. The practice effect is associated with performance improvements that follow from getting more experience with the test; the memory effect is associated with performance improvements that follow from the recollection of specific sentences. The practice effect evolves continuously with each sentence that is presented, while memory only affects performance when sentences are reused with the same listener. In the validation experiments of the present study, a practice effect was estimated from the improvements in the listeners' performance during their first test session. In a validation retest after three weeks, where the sentence lists from the first test session were reused, a combined learning effect (practice and memory) was assessed. The distribution of the learning effect between practice and memory in such a retest was investigated in an additional experiment with $\mathrm{HI}$ listeners.

\section{From CLUE to a Danish HINT}

\section{Test of naturalness}

The naturalness of the CLUE sentences was judged by a panel of 10 native and 'naive' Danish speakers and by two professional linguists. For various reasons, 15 of the practice sentences were rejected in advance, leaving 235 sentences for the naturalness test. The panel judged the written version of the sentences on a scale from 1 (= 'artificial') to 7 (= 'natural'). The requirements for a sentence to be 'natural' were (1) that it did not contain unusual Danish words; and (2) that it could have been used in an ordinary conversation. A mean rating of 5 or above among the naive participants was set as the requirement for including a sentence in the test lists. In addition, up to three sentences with a score between 4.0 and 4.9 would be accepted in each test list. A score of 5 or above was achieved by 176 sentences, and 41 sentences received a score between 4.0 and 4.9. A sufficient number of 'natural' sentences were thus available to compile 10 new 20 -sentence lists.

\section{Generation of the test lists}

The 18 original CLUE test lists and two of the CLUE practice lists were combined to create ten 20 -sentence lists. The CLUE list with the lowest mean speech recognition threshold in noise $\left(\mathrm{SRT}_{\mathrm{N}}\right)$, as determined during the CLUE validation process, was successively paired with the list with the highest $\mathrm{SRT}_{\mathrm{N}}$ in an attempt to achieve lists with equalized $\mathrm{SRT}_{\mathrm{N}} \mathrm{s}$. In these lists, the 'unnatural' sentences were exchanged with sentences from the pool of 'natural' sentences, preferring those with a higher naturalness score. The exchanged sentences were reshuffled among the lists by a computer-based trial-anderror routine in order to maintain the phonetic balance between the lists as closely as possible (Nielsen \& Dau, 2009). It was observed that the 24 sentences with a naturalness score of 4.0 to 4.9 had been distributed with two or three sentences in each list. Three practice lists were compiled from the sentences that were deemed 'unnatural' or omitted at previous stages.

\section{Permitted response variations}

A new set of rules for permitted variations in the listener response was created for the Danish HINT; the main difference from the CLUE scoring rules was the omission of alternatives for some specific words. The final scoring rules for the Danish HINT permit the following response variations: (1) change in verb tense; (2) change in article; (3) change between singular and plural nouns; (4) reordering of words; (5) addition of extra words or phones; and (6) omission of a single phone (e.g. the [t] that changes adjectives to adverbs in Danish). Several variations are permitted in a single response.

\section{Test validation with $\mathrm{NH}$ and HI listeners}

The purpose of the validation was to establish normative data for the test and to investigate the test reliability. Normative data can only be established for NH listeners, whereas the reliability can be judged for both $\mathrm{NH}$ and $\mathrm{HI}$ listeners from the within-subject standard deviation of the $\mathrm{SRT}_{\mathrm{N}}$ and the variation of the mean $\mathrm{SRT}_{\mathrm{N}}$ of the test lists. All listeners participated in a retest after three weeks.

\section{Method}

\section{LISTENERS}

Sixteen ( 8 male, 8 female) NH listeners and sixteen HI listeners (10 male, 6 female) participated in the validation. Participation was approved by the ethics committee of Copenhagen County. The NH 
listeners' age was between 19 and 43, with a mean of 33.6 years. The requirements for participation were: (1) age 18-45 years; (2) hearing threshold $\leq 20 \mathrm{~dB} \mathrm{HL}$ at both ears $(0.125$ to $8 \mathrm{kHz})$, yet a threshold of $25 \mathrm{~dB}$ HL was allowed at one frequency per ear; (3) Danish as native language; (4) no previous experience with CLUE; and (5) variation in the educational background for the group.

The age of the HI listeners was between 61 and 69 (mean 65.9 years) and the requirements for participation were: (1) Age 60-70 years; (2) a hearing loss caused by presbyacusis, reflecting symmetrical mild-to-moderate sloping hearing loss; (3) at least one year of experience with wearing a hearing aid; (4) Danish as native language; (5) experience with DANTALE II (Wagener et al, 2003); (6) no previous experience with CLUE; and (7) variation in the educational background for the group.

\section{APPARATUS AND PROCEDURE}

The validation tests took place in a soundproof booth and the stimuli were presented diotically over Sennheiser HD580 headphones. The sound level was calibrated using the ear simulator and flat plate adaptor specified in IEC 60318-1 (2009), and a Brüel and Kjær measuring amplifier (type 2636). All testing was conducted without the use of hearing aids. The tests were conducted according to the standard HINT procedure (Bio-logic Systems Corp., 2005), controlled by a MATLAB application. The order of the sentences within each list was randomized before presentation of the list. The listeners received oral instructions before the test and were encouraged to guess if necessary when responding to the presented sentences. Each listener was tested with all 10 test lists. The order of the test lists was counterbalanced across listeners (using Latin squares) to avoid order effects. A short break was included after completion of the first five lists.

In order to familiarize the listeners with the task and to reduce the practice effect during the validation, a training procedure was conducted before the actual test. For the NH listeners, two practice lists in noise were presented. For the HI listeners, this procedure was preceded and extended by two practice lists in quiet in order to introduce the test smoothly and to determine an appropriate noise level for the subsequent list presentations in noise. The speech recognition threshold in quiet $\left(\mathrm{SRT}_{\mathrm{Q}}\right.$ ) of the second practice list determined the level of the noise. If $\mathrm{SRT}_{\mathrm{Q}} \leq 45 \mathrm{~dB}(\mathrm{~A})$, the noise level was fixed at $65 \mathrm{~dB}(\mathrm{~A})$. If $\mathrm{SRT}_{\mathrm{Q}}>45 \mathrm{~dB}(\mathrm{~A})$, the noise level was fixed at $\mathrm{SRT}_{\mathrm{Q}}$ $+20 \mathrm{~dB}$. This determination of the level for HI listeners followed the current HINT recommendations (Bio-logic Systems Corp., 2005). For the NH listeners, the noise level was always fixed at $65 \mathrm{~dB}(\mathrm{~A})$.

The retest three weeks later followed the same schedule and procedure as the test, except that the practice lists in quiet were not presented. The individual noise levels determined during the first visit were also used in the retest. The order of the lists was the same as during the test, but the randomization of the sentences within the lists was different.

\section{Results}

\section{VALIDATION}

All $\mathrm{SRT}_{\mathrm{N}} \mathrm{S}$ in the present study were calculated according to the current HINT standard (Soli \& Wong, 2008). The overall $\mathrm{SRT}_{\mathrm{N}}$ across test lists and $\mathrm{NH}$ listeners was $-2.52 \mathrm{~dB}$ with a standard deviation of $0.87 \mathrm{~dB}$; the within-subject standard deviation was $0.86 \mathrm{~dB}$. For the $\mathrm{HI}$ listeners, the overall $\mathrm{SRT}_{\mathrm{N}}$ was $0.09 \mathrm{~dB}$ with a standard deviation of $1.79 \mathrm{~dB}$; the within-subject standard deviation was $0.92 \mathrm{~dB}$.

For each of the 10 lists, a mean list-SRT ${ }_{N}$ across the listeners was calculated. A normalized result is shown in Figure 1 for the $\mathrm{NH}$ listeners (black circles) and the HI listeners (grey circles). For the $\mathrm{NH}$ listeners, the list-SRT $\mathrm{T}_{\mathrm{N}}$ standard deviation was $0.32 \mathrm{~dB}$ and the maximum deviation from the overall mean was $0.63 \mathrm{~dB}$. For the HI listeners, the list-SRT $\mathrm{N}_{\mathrm{N}}$ standard deviation was $0.39 \mathrm{~dB}$ and the maximum deviation from the overall mean was $0.60 \mathrm{~dB}$. The normalized list$\mathrm{SRT}_{\mathrm{N}} \mathrm{s}$ were similar for the two groups; the largest deviation of 0.50 $\mathrm{dB}$ was observed for list 2. However, even for this list, an unpaired t-test did not show a significant difference between the list-SRT for $_{\mathrm{N}}$ the two groups [p $=0.15]$.

For the NH listeners, a two-way ANOVA showed a significant effect of list at a 0.05 level but not at a 0.01 level $[\mathrm{F}(9,135)=2.37$, $\mathrm{p}=0.016]$. There was no significant effect of listener $[\mathrm{F}(15,135)$ $=1.34, \mathrm{p}=0.19]$. A corresponding analysis of the HI data showed a significant effect of list $[\mathrm{F}(9,135)=3.28, \mathrm{p}=0.0012]$, and a highly significant effect of listener $[\mathrm{F}(15,135)=35.31, \mathrm{p}<0.0001]$.

Figure 2 shows the mean $\mathrm{SRT}_{\mathrm{N}}$ across the 10 test lists for each of the NH listeners (black circles) and each of the HI listeners (grey circles). The subject-SRT ${ }_{N}$ variation among the HI listeners was $6 \mathrm{~dB}$ and thus much larger than for the NH listeners $(1.1 \mathrm{~dB})$.

\section{PSYCHOMETRIC FUNCTIONS}

The psychometric function of the test was determined for each individual listener. The data points were based on the percentage of correctly repeated sentences at each of the signal-to-noise ratios (SNRs) of the adaptive procedure. (The adaptive procedure makes presentations that only deviate $0.2 \mathrm{~dB}$ SNR from each other possible. These presentation levels were pooled in bins of one $\mathrm{dB}$ around the integer values of the SNR.) The sentences at list positions 5-20 in the 10 test lists were included in the calculation, resulting in 160 data points for each listener. For each listener, a cumulative normal distribution function was fitted to the data, estimating a psychometric function. For the NH listeners, the steepest slope of these curves varied from 10.9 to $20.7 \% / \mathrm{dB}$ with a mean value of $16.8 \% / \mathrm{dB}$. For the HI listeners, the steepest slope varied from 7.5 to $24.1 \% / \mathrm{dB}$ with a mean value of $14.7 \% / \mathrm{dB}$. The steepest slopes of the psychometric functions are shown in Figure 3 as a function of the corresponding subject-SRT $\mathrm{N}_{\mathrm{N}}$ for each listener. For the HI listeners (grey circles),

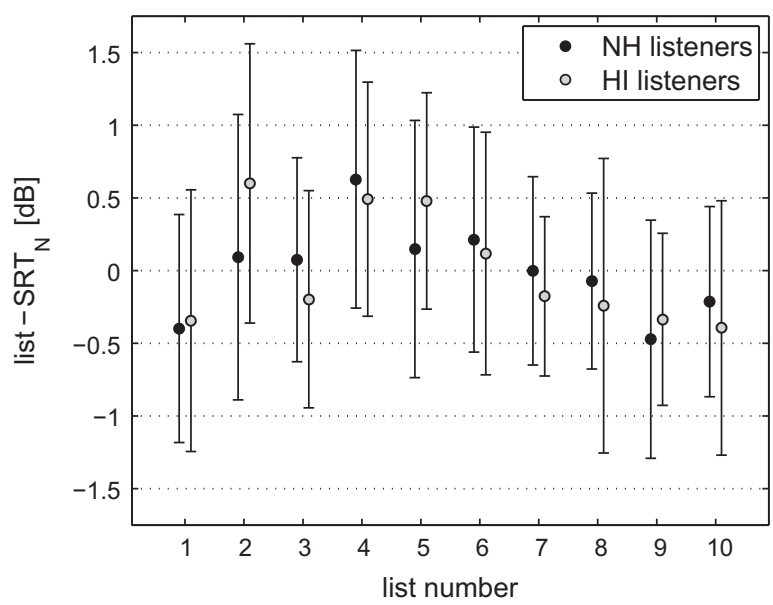

Figure 1. The normalized list-SRT $\mathrm{S}_{\mathrm{N}}$ (mean across listeners) based on the validation test with $16 \mathrm{NH}$ listeners (black circles) and the $16 \mathrm{HI}$ listeners (grey circles). The figure is based on $\mathrm{SRT}_{\mathrm{N}} \mathrm{s}$ that are normalized for each subject with respect to the individual subject$\mathrm{SRT}_{\mathrm{N}}$ (mean $\mathrm{SRT}_{\mathrm{N}}$ across lists). The bars indicate \pm 1 standard deviation. 


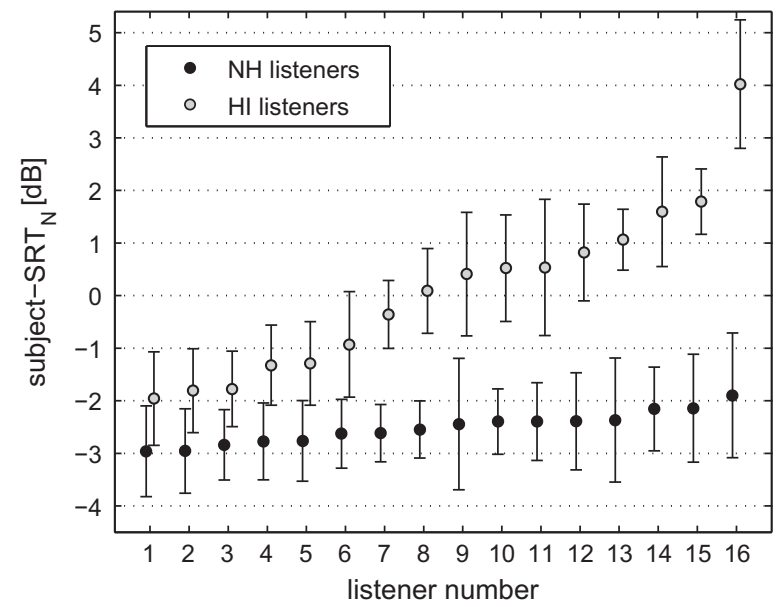

Figure 2. The absolute subject-SRT $\mathrm{T}_{\mathrm{N}} \mathrm{s}$ measured during validation with $16 \mathrm{NH}$ listeners (black circles) and validation with $16 \mathrm{HI}$ listeners (grey circles). For each group, the listeners are sorted with respect to their mean $\mathrm{SRT}_{\mathrm{N}}$. The bars indicate \pm 1 standard deviation.

there was a significant correlation between the slope of the psychometric function and the $\mathrm{SRT}_{\mathrm{N}}[\mathrm{r}=-0.65]$. For the NH listeners (black circles), no significant correlation was found $[\mathrm{r}=-0.03]$. An unpaired t-test did not show a significant difference between the mean of the steepest slopes for the $16 \mathrm{NH}$ listeners (black square) and that for the $16 \mathrm{HI}$ listeners (grey square) [p $=0.15]$.

\section{PRACTICE EFFECT DURING THE TEST}

Figure 4 shows the mean $\mathrm{SRT}_{\mathrm{N}}$ as a function of the list position during the test sessions. For each position, the $\mathrm{SRT}_{\mathrm{N}}$ was determined as the mean across the combinations of listeners and lists at that position during the test $(n=16)$, calculated separately for the $\mathrm{NH}$ listeners (black circles) and the HI listeners (grey circles). The data were normalized with respect to list-SRT $\mathrm{N}_{\mathrm{N}}$ and subject-SRT $\mathrm{N}_{\mathrm{N}}$, i.e.

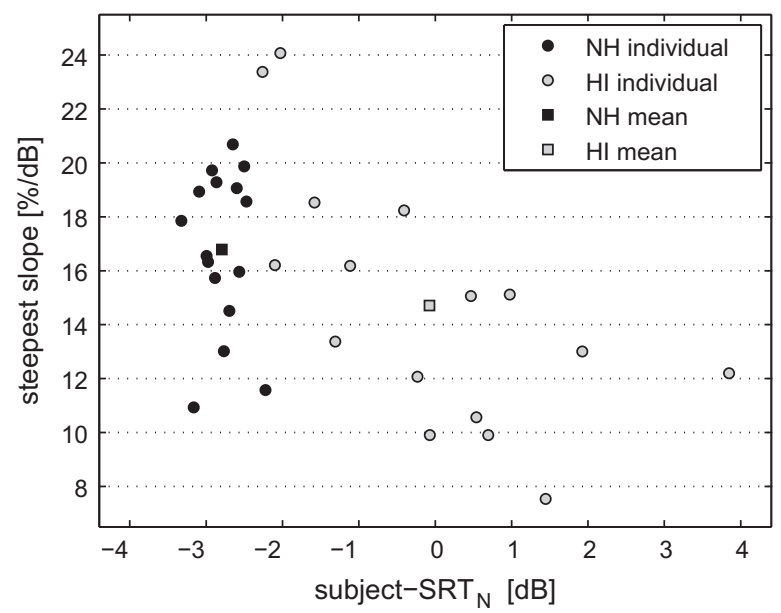

Figure 3. Steepest slope of the psychometric functions for the $\mathrm{NH}$ listeners (black circles) and the HI listeners (grey circles) as a function of the corresponding subject-SRT $\mathrm{T}_{\mathrm{N}}$. The slopes are based on a fitted cumulative normal distribution function for each listener. The mean slope and mean subject-SRT $\mathrm{T}_{\mathrm{N}}$ for the two groups are marked by squares.

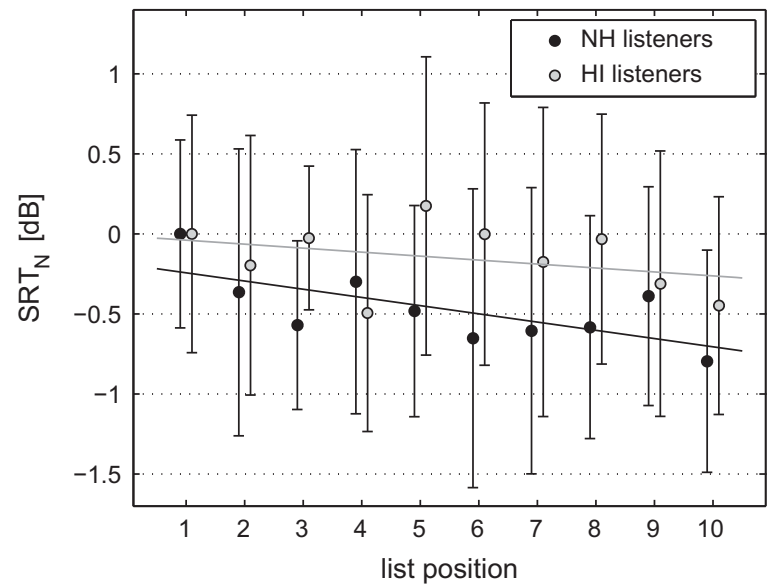

Figure 4. The mean $\mathrm{SRT}_{\mathrm{N}}$ across lists and listeners as a function of the list position during the test session. Data are adjusted with respect to the mean $\mathrm{SRT}_{\mathrm{N}}$ of position 1. Bars indicate \pm 1 standard deviation. The black linear regression line is a best fit to the means for the $\mathrm{NH}$ listeners; the grey line is a similar fit for the HI listeners. The decreasing trend indicates improved performance due to practice.

the effects of list and listener were removed. A linear regression line was fitted to the data for the 10 list positions; the slopes were (with $95 \%$ confidence intervals): $-0.05[-0.09,-0.008] \mathrm{dB} /$ position for the NH listeners and $-0.025[-0.08,0.03] \mathrm{dB} /$ position for the HI listeners. For the NH listeners, the major effect of practice seemed to occur during the two first list presentations. If these two presentations were taken out of the linear regression, the slope would reduce to $-0.027[-0.08,0.03] \mathrm{dB} /$ position. Thus, a significant practice effect was only observed for the $\mathrm{NH}$ listeners and only when the effect was considered over all 10 list presentations.

\section{Test-retest learning effect}

Figure 5 compares the list-SRT $\mathrm{N}_{\mathrm{N}} \mathrm{s}$ in the test (filled symbols) and the retest (open symbols). Accordingly, Figure 6 compares the

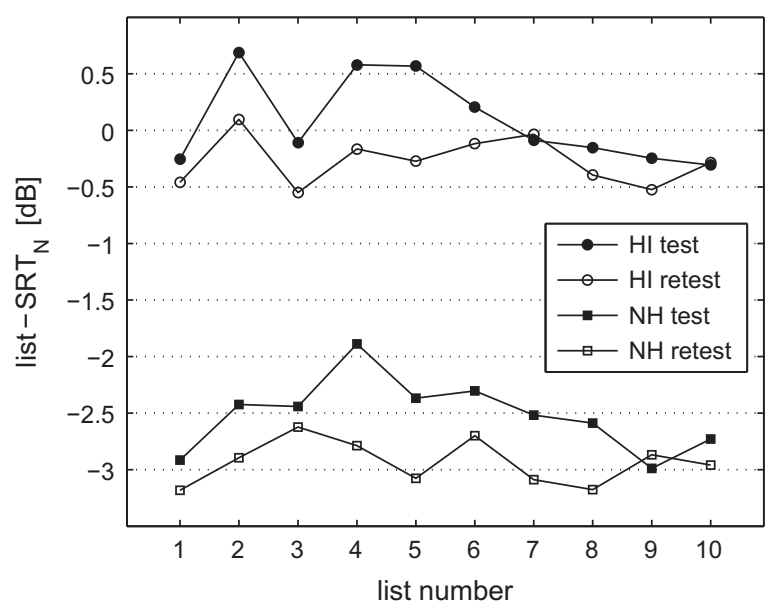

Figure 5. Comparison of the list-SRT $\mathrm{N}_{\mathrm{N}} \mathrm{s}$ (mean across listeners) in test and retest for the 10 test lists. The lower curves compare the results for the $\mathrm{NH}$ listeners (filled and open squares); the upper curves compare the results for the HI listeners (filled and open circles). 


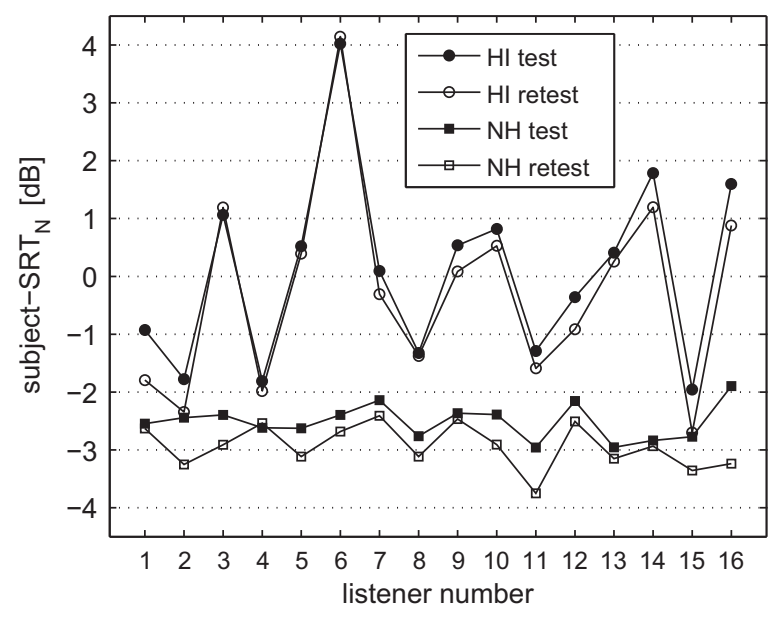

Figure 6. Comparison of the subject-SRT $\mathrm{N}_{\mathrm{N}} \mathrm{s}$ (mean across lists) in test and retest for the $16 \mathrm{NH}$ listeners (filled and open squares) and the $16 \mathrm{HI}$ listeners (filled and open circles).

subject-SRT $\mathrm{N}_{\mathrm{N}} \mathrm{S}$ in the test (filled symbols) and in the retest (open symbols). In the retest, the overall $\mathrm{SRT}_{\mathrm{N}}$ across test lists and listeners was $-2.94 \mathrm{~dB}$ for the $\mathrm{NH}$ listeners, a decrease of $0.42 \mathrm{~dB}$ compared to the initial test due to learning effects (practice and memory). The overall $\mathrm{SRT}_{\mathrm{N}}$ standard deviation was $0.75 \mathrm{~dB}$ and the within-subject standard deviation was $0.69 \mathrm{~dB}$. A two-way ANOVA showed no significant effect of list $[\mathrm{F}(9,135)=1.31, \mathrm{p}=0.24]$, but a significant effect of listener $[\mathrm{F}(15,135)=3.06, \mathrm{p}=0.0003]$.

For the HI listeners, the overall $\mathrm{SRT}_{\mathrm{N}}$ in the retest was $-0.27 \mathrm{~dB}$, a decrease of $0.36 \mathrm{~dB}$ compared to the initial test. The overall $\mathrm{SRT}_{\mathrm{N}}$ standard deviation was $1.86 \mathrm{~dB}$ and the within-subject standard deviation was $0.83 \mathrm{~dB}$. A two-way ANOVA showed no significant effect of list $[\mathrm{F}(9,135)=1.09, \mathrm{p}=0.37]$, but a highly significant effect of listener $[\mathrm{F}(15,135)=44.6, \mathrm{p}<0.0001]$.

\section{Discussion}

The Danish HINT evaluated in this study produces normative data that are comparable to other language versions of HINT. The $\mathrm{SRT}_{\mathrm{N}}$ for the $\mathrm{NH}$ listeners is $-2.5 \mathrm{~dB}$, which falls slightly outside the range of -5.3 to $-2.6 \mathrm{~dB}$ observed for the 13 versions of HINT listed in Soli \& Wong (2008). The relatively high $\mathrm{SRT}_{\mathrm{N}}$ for the Danish test might be caused by the complexity of the sentences and the use of a non-professional talker. This does not necessarily represent a disadvantage of the test. One of the goals of creating a new test was to achieve a normative $\mathrm{SRT}_{\mathrm{N}}$ that is considerably higher than that of existing Danish tests such as the DANTALE II test $(-8.4 \mathrm{~dB}$; Wagener et al, 2003). The normative standard deviation of the $\mathrm{SRT}_{\mathrm{N}}$ for the Danish HINT, $0.87 \mathrm{~dB}$, is similar to the mean for the HINTs reported in Soli \& Wong (2008).

The observed effect of list in the validation test with $\mathrm{NH}$ listeners corresponds to the results obtained for the American HINT (Nilsson et al, 1994) and the Swedish HINT (Hällgren et al, 2006). Although the list effect is significant at a 0.05 level, a post-hoc analysis with a Bonferroni correction $(n=10)$ showed that none of the list-SRT ${ }_{N} S$ deviated significantly from the overall $\mathrm{SRT}_{\mathrm{N}}$ at a 0.05 level. A similar result is obtained when performing a post-hoc analysis of the validation data for the HI listeners. Thus, the post-hoc analysis of the validation results does not indicate that certain lists should be avoided when using the Danish HINT for SRT measurements.
The overall SRT $\mathrm{N}_{\mathrm{N}}$ for the HI listeners $(0.09 \mathrm{~dB})$ was found to be $2.6 \mathrm{~dB}$ higher than for the $\mathrm{NH}$ listeners $(-2.52 \mathrm{~dB})$. This suggests that the test is sensitive to the listeners' ability to follow a conversation in noise. For the HI listeners, the noise level was fixed at $20 \mathrm{~dB}$ above the $\mathrm{SRT}_{\mathrm{Q}}$ (or minimum $65 \mathrm{~dB}(\mathrm{~A})$ ). This approach reduces the role of audibility and increases the sensitivity of the $\mathrm{SRT}_{\mathrm{N}}$ to other speech-reception difficulties such as cognitive factors. However, reduced audibility in some frequency regions may still explain part of the poorer performance for some of these listeners.

The within-subject standard deviation of $0.92 \mathrm{~dB}$ for the HI listeners was found to be only marginally larger than the value of 0.86 $\mathrm{dB}$ for the NH listeners. Thus, the reliability of the test seems similar for the two groups. However, this result may partly be explained by the HI listeners' previous experience with DANTALE II; this was one of the requirements for their participation in the present study. Trained listeners are typically more focussed on the task and show a more reliable performance than untrained listeners. This may have reduced the within-subject standard deviation.

During the presentation of the 10 test lists, the practice effect was small in both listener groups, but particularly small for the HI listeners. If the two first test lists were omitted from the calculations for the NH listeners, the effect would reduce to the same level as for the HI listeners. This suggests that the smaller effect observed for the HI listeners could be due to the two additional practice lists that were presented before the actual test session. It thus seems that running four practice lists instead of only two can significantly reduce the progression of the practice effect during the following list presentations.

The similar results obtained in the test and the retest both for $\mathrm{NH}$ and $\mathrm{HI}$ listeners suggest that the test can be reused after three weeks. The decrease of the overall $\mathrm{SRT}_{\mathrm{N}}$ of $0.4 \mathrm{~dB}$ from test to retest for both listener groups is too small to affect the functionality of the test. Furthermore, the within-subject standard deviation was reduced in the retest and the significant effect of list observed in the initial test was not observed in the retest.

\section{Effects of practice and memory}

An additional experiment was performed with a new group of $\mathrm{HI}$ listeners. The purpose was to estimate how the learning effect is distributed between practice and memory when sentences are reused with the same listeners. The effects were estimated from the difference in the listeners' average performance during an initial test and a retest. The within-session progression of the practice effect, as depicted in Figure 4, was not investigated here.

\section{Method}

\section{LISTENERS}

Twelve ( 9 male, 3 female) HI listeners participated. Participation was approved by the ethics committee of Copenhagen County. Their age was between 59 and 72 years, mean 64.8 years. The requirements for the listeners in this group were the same as for the previous HI group (although the age requirement was slightly violated for three listeners).

\section{PROCEDURE}

The experiment was divided in two sessions; the second visit took place three weeks after the first (five and a half weeks later for one of the listeners). The practice and the test procedures were similar to 
those of the test validation experiments. The only major difference was that only five test lists were presented at the first visit. During the experiment, subsets of the 10 test lists were presented in three conditions: (1) five unknown lists presented at the first visit ("first visit test'); the test results in this condition were not affected by any memory effect; (2) five unknown lists presented at the second visit ('second visit test'); these results were affected by the progression of the average practice effect between the first and the second visit, but still not affected by memory; and (3) the five lists from the first visit presented again at the second visit ('second visit retest'); the results in this condition were affected by both memory and a change in the average practice effect. The practice component of the learning effect can thus be estimated from the $\mathrm{SRT}_{\mathrm{N}}$ difference between 'first visit test' and 'second visit test'. The memory component can be estimated from the $\mathrm{SRT}_{\mathrm{N}}$ difference between 'second visit test' and 'second visit retest'.

The test lists of the first visit were counterbalanced across listeners and each list was included in half (six) of the subsets. The order of the lists was also counterbalanced to avoid order effects. During the second visit, the order of the five previously presented lists was the same as during the first visit. The five new lists and their order were counterbalanced across listeners. The previously presented and the new lists interleaved through the second session.

\section{Results}

Three mean $\mathrm{SRT}_{\mathrm{N}} \mathrm{s}$ were calculated for each listener: (1) the mean $\mathrm{SRT}_{\mathrm{N}}$ across the five lists presented at the first visit; (2) the mean $\mathrm{SRT}_{\mathrm{N}}$ across the five lists presented for the first time at the second visit; and (3) the mean $\mathrm{SRT}_{\mathrm{N}}$ across the five lists presented for the second time during the second visit. For each listener, the means were normalized with respect to the mean $\mathrm{SRT}_{\mathrm{N}}$ of the 'second visit test' in order to remove the large $\mathrm{SRT}_{\mathrm{N}}$ differences between listeners. The results are shown in Figure 7. The mean $\mathrm{SRT}_{\mathrm{N}} \mathrm{s}$ across

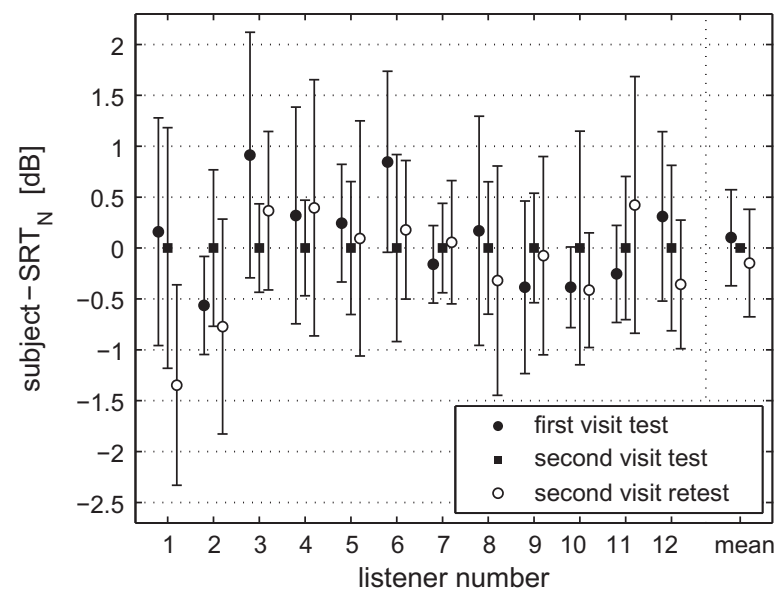

Figure 7. Comparison of the subject-SRT $\mathrm{N}_{\mathrm{N}} \mathrm{s}$ determined across five lists in three conditions. 'First visit test' results are not affected by the learning effects under investigation (practice and memory). 'Second visit test' results are affected by practice, but not memory. 'Second visit retest' results are affected by both practice and memory. For each subject, the results are normalized with respect to the $\mathrm{SRT}_{\mathrm{N}}$ of the 'second visit test'. The bars indicate \pm 1 within-subject standard deviation. The 'mean' entry indicates the overall mean in the three conditions with \pm 1 standard deviation of the subject means. listeners in the three conditions were: $0.10 \mathrm{~dB}$ for 'first visit test'; $0 \mathrm{~dB}$ for 'second visit test'; and $-0.15 \mathrm{~dB}$ for 'second visit retest'. The estimate for the change in the average practice effect from test to retest is thereby $-0.10 \mathrm{~dB}$. The pure memory effect is estimated to be $-0.15 \mathrm{~dB}$.

\section{Discussion}

The difference in learning effect (practice and memory) from test to retest can be estimated to $-0.25 \mathrm{~dB}$. This is slightly lower than for the previous group of $\mathrm{HI}$ listeners $(-0.36 \mathrm{~dB})$, probably because only five test lists were presented during the first visit (instead of 10). The memory effect $(-0.15 \mathrm{~dB})$ seems to be slightly larger than the practice effect $(-0.10 \mathrm{~dB})$. However, the estimate of the memory effect was dominated by the particularly large effect observed for listener 1. Omitting this result from the calculation would reduce the memory effect to $-0.04 \mathrm{~dB}$.

The results from the present experiment confirm the results obtained with the NH listeners and the previous group of HI listeners (Figure 6) that the $\mathrm{SRT}_{\mathrm{N}}$ change between test and retest is within $0.5 \mathrm{~dB}$ for most listeners. The results also indicate that only half or probably less of the $\mathrm{SRT}_{\mathrm{N}}$ decrease between test and retest is due to a memory effect.

\section{Conclusion}

A Danish HINT with 10 test lists and three practice lists was developed. The test lists and practice list are shown in the Appendix. The test validation with $\mathrm{NH}$ listeners produced normative data that are comparable to those of other language versions of HINT (Soli $\&$ Wong, 2008). The normative $\mathrm{SRT}_{\mathrm{N}}$ of $-2.5 \mathrm{~dB}$ for the Danish HINT is slightly above that obtained with other HINTs, and it is substantially higher than the value obtained with another Danish speech test, DANTALE II (Wagener et al, 2003).

The validation with $\mathrm{HI}$ listeners led to $\mathrm{SRT}_{\mathrm{N}}$ assessments with a within-subject deviation and a between-list deviation that was only slightly different from those obtained with $\mathrm{NH}$ listeners. The test is thus expected to produce equally reliable results for $\mathrm{NH}$ and $\mathrm{HI}$ listeners.

The test and retest with a three-week interval showed only small differences in the measured $\mathrm{SRT}_{\mathrm{N}} \mathrm{s}$. Changes in the subject-SRT $\mathrm{N}_{\mathrm{N}}$ were generally within $0.5 \mathrm{~dB}$. Reuse of the test lists after three weeks thus seems possible. The investigation of the separated practice and memory effects suggested that recollection of the sentences only accounts for a minor part of the $\mathrm{SRT}_{\mathrm{N}}$ decrease between test and retest.

\section{Acknowledgements}

This study was conducted in collaboration with the Danish hearing aid companies Oticon, GN Resound, and Widex. We wish to thank the following colleagues for their contributions and involvement: Lise Bruun Hansen and Niels Søgaard Jensen (Oticon); Anja Kofoed Pedersen and Ellen Raben Pedersen (Widex); Charlotte T. Jespersen, Jenny Nesgaard, and Lotte Hernvig (GN Resound). We would also like to thank Julie Neel Weile for running the tests with the many HI listeners. Finally, thank you to all the listeners who took time to participate. The present work was partly funded by the Oticon Foundation.

\section{Note}

Audio files of the Danish HINT and the written sentence lists can be found at http://informahealthcare.com/doi/abs/10.3109/1499202 7.2010.524254. 
Declaration of interest: The authors report no conflicts of interest. The authors alone are responsible for the content and writing of the paper.

\section{References}

Bio-logic Systems Corp. 2005. HINT Pro: Hearing in Noise Test User's and Service Manual. Mundelein, Illinois: Bio-logic Systems Corp.

Hällgren M., Larsby B. \& Arlinger S. 2006. A Swedish version of the hearing in noise test (HINT) for measurement of speech recognition. Int $J$ Audiol, 45, 227-237.

IEC 60318-1 2009. Electroacoustics - Simulators of human head and ear - Part 1: Ear simulator for the measurement of supra-aural and circumaural earphones. Geneva: International Electrotechnical Commission.
McArdle R.A. \& Wilson R.H. 2006. Homogeneity of the 18 QuickSIN Lists. J Am Acad Audiol, 17, 157-167.

Nielsen J. B. \& Dau T. 2009. Development of a Danish speech intelligibility test. Int J Audiol, 48, 729-741.

Nilsson M., Soli S.D. \& Sullivan J. A. 1994. Development of the hearing in noise test for the measurement of speech reception thresholds in quiet and in noise. J Acoust Soc Am, 95, 1085-1099.

Soli S. D. \& Wong L. L. N. 2008. Assessment of speech intelligibility in noise with the hearing in noise test. Int J Audiol, 47, 356-361.

Vaillancourt V., Laroche C., Mayer C., Basque C., Nali M. et al. 2005. Adaptation of the HINT (hearing in noise test) for adult Canadian Francophone populations. Int J Audiol, 44, 358-369.

Wagener K., Josvassen J. L. \& Ardenkjaer R. 2003. Design, optimization, and evaluation of a Danish sentence test in noise. Int J Audiol, 42, 10-17.

Wong L. L. N. \& Soli S. D. 2005. Development of the Cantonese hearing in noise test (CHINT). Ear Hear, 26, 276-289.

\section{Supplementary material available online}

Appendix 
Supplementary Material for Nielsen JB \& Dau T. The Danish hearing in noise test. International Journal of Audiology, 2010, doi 10.3109/14992027.2010.524254.

\section{Appendix.}

\section{Test list 1}

1) Det var en god fastelavnsfest

2) Kampen skal spilles på onsdag

3) Filmen er rigtig godt lavet

4) Derhjemme spiser vi ikke kød

5) Børnene løber rundt og leger

6) Hun kommer meget i teatret

7) Familien går tur i parken

8) Statuen har ikke noget hoved

9) Hun tog en hurtig beslutning

10) Vi snakkede med vores venner

11) Billetterne bliver sendt til os

12) Bussen kan ikke komme frem

13) Posen her er til grøntsager

14) Han sluttede som nummer fire

15) Chokoladen var dyr og god

16) Byen ser fantastisk dejlig ud

17) Jeg skulle ringe til formanden

18) Vi sagde farvel til gæsterne

19) Bakken er halvtreds meter høj

20) Arbejdet er hårdt og krævende

Test list 2

1) Reden er bygget af smågrene

2) Jeg ønsker mig et kæledyr

3) Han var verdensmester i svømning

4) De cykler eller tager bilen

5) Huset lå omme bag torvet

6) Jeg spurgte ikke til prisen

7) De ankom sidst på formiddagen

8) Hun rider på venindens hest

9) Insekter kan flyve meget langt

10) De har altid boet hjemme

11) Mødet skal holdes på skolen

12) Udenfor er det fuldstændig mørkt

13) Hun var omgivet af mennesker

14) Børnene kom hjem ved middagstid

15) Snakken ved bordet var livlig

16) Alle foredrag er på engelsk

17) Af og til larmer naboerne

18) De blev hurtigt gode venner

19) Han afviste det nye forslag

20) Koden til låsen passer ikke

Test list 3

1) Om morgenen lagde stormen sig

2) Lyden kommer oppe fra loftet

3) Hun har købt en vinterfrakke

4) Grisene løber frit på marken

5) Han talte til en kollega

6) Bagefter skal vi have jordbær

7) Musik giver en god stemning

8) Spillerne troede på sig selv

9) Tapetet var faldet af væggen

10) Hun havde de smukkeste øjne

11) Hver aften spiser de salat

12) Mandag vågnede vi meget sent

13) Hendes far var ikke hjemme

14) Han er tilfreds med artiklen

15) Klokken var blevet over midnat

16) Båndet blev revet i stykker
17) Butikken holder et stort udsalg

18) Hun lavede en kop kaffe

19) Nu venter landmændene på regn

20) De kommer sejlende til byen

\section{Test list 4}

1) Pigen strikker en rød trøje

2) Vi ventede længe i køen

3) Om aftenen var der lejrbål

4) Det kilder lidt i fingeren

5) Hun gik hen til telefonen

6) Vi skal bare blive siddende

7) Kunden er tilfreds med svaret

8) Huset her er hans barndomshjem

9) Redskaber skal sættes på plads

10) Vejrudsigten lover regn og slud

11) Godt håndværk holder $i$ årevis

12) Min kuglepen skriver med rødt

13) Mødet sluttede efter tre timer

14) Han ønskede sig en jakke

15) Jeg er ikke længere sulten

16) Han købte ikke mange blomster

17) Villaen er ikke blevet solgt

18) Hjælpen nåede frem for sent

19) Hendes bror vil være brandmand

20) Han lagde tasken på bordet

Test list 5

1) Børnene sidder i en rundkreds

2) Gæsterne nyder den gode vin

3) Manden ville løbe en tur

4) De talte lidt om fremtiden

5) Pladsen var spærret af affald

6) Festen varede til over midnat

7) Manden kløede sig på armen

8) Hun havde ingen frakke på

9) De ønsker sig et sommerhus

10) Begge hold scorede otte mål

11) Stuen skal nok blive hyggelig

12) Døren er næsten aldrig åben

13) Han blev en god skolelærer

14) De engelske bøffer var møre

15) Han kunne køre meget stærkt

16) Sofaen står bagerst i rummet

17) Torsdag var han ikke hjemme

18) Begge fodboldhold klarer sig fint

19) Maden blev serveret til tiden

20) Han havde let ved hovedregning

Test list 6

1) Nu skal maskinerne skiftes ud

2) Renten var kun fire procent

3) Jeg tager fat i dørhåndtaget

4) Tøjet var gået af mode

5) Her går alle med solbriller

6) Kassedamen så venligt på ham

7) Han ligger stadig i sengen

8) Eleven skriver en lang rapport

9) Hele byen kom til brylluppet

10) Vi så lidt af vejrudsigten

11) Toget er meget sjældent fuldt

12) Jeg var også utrolig glad 
13) Hans datter vil på højskole

14) I går havde filmen premiere

15) Fabrikkens port var ikke lukket

16) Hendes tøj var helt gennemblødt

17) Bilen er ikke længere ny

18) Nu begynder en ny sæson

19) Flyrejsen varer mindst fem timer

20) Jeg sætter mig nede bagved

\section{Test list 7}

1) Lakken skal fjernes fra gulvet

2) Han kan lugte hendes parfume

3) Værelset lå ud til baggården

4) Naboerne var med til middagen

5) Lyskrydset skifter snart til rødt

6) Han er en flittig musiker

7) Vi havde en dejlig weekend

8) Udsigten er bedst om sommeren

9) Hendes øjne så trætte ud

10) Vi får boller og chokolade

11) Skuret er bygget af brædder

12) Hans mor var heldigvis hjemme

13) De to mænd kender hinanden

14) Holdet er klar til kampen

15) De skal bo på efterskolen

16) Hendes penge var gået tabt

17) Alle skal betale samme pris

18) Blomster og gaver strømmede ind

19) Hun var i strålende humør

20) Vi er en fredelig familie

\section{Test list 8}

1) Skuffen kunne ikke lukkes helt

2) Vi byggede husene af træ

3) I morgen bliver vejret bedre

4) Han hoppede op på cyklen

5) Han har aldrig lavet middagsmad

6) Udsigten til skoven var god

7) Motorløb kan være ret farligt

8) Vi rister pølser over bålet

9) Manden kom til en benzintank

10) Han kender alle byens gader

11) Pigen var køn og velbegavet

12) Vi sad ude i køkkenet

13) Flasken var fyldt med æblesaft

14) Rejsen varer mindst en uge

15) De danser på et diskotek

16) Bageren havde tre slags rugbrød

17) Han kommer mandag med pakken

18) Tårnet er ikke særlig højt

19) Hun var en lille solstråle

20) De kom kørende i hestevogn

Test list 9

1) Strømperne var gået i stykker

2) Høsten var allerede i hus

3) Vi havde en festlig aften

4) Man skal holde korte pauser

5) Han taler om sit arbejde

6) Hendes kontor ligger langt væk

7) Din bror er meget utålmodig

8) Bogen er fuld af eksempler

9) Manden skal ringe til hende

10) Jeg går ud på dansegulvet

11) Vinderen fik en flot pokal

12) Hunden svømmede væk fra kysten

13) Hans søster var blevet klippet
14) Han læser med stærke briller

15) Pludselig kom der en lastbil

16) Der var altid åbent tirsdag

17) Mine venner går i gymnasiet

18) Bogen er skrevet på engelsk

19) Der bor mange mennesker her

20) Hun var taget på arbejde

\section{Test list 10}

1) Kurven var fyldt med vasketøj

2) Første stop er ved svømmehallen

3) Han lagde brænde på bålet

4) Folk sidder og taler sammen

5) Hun var bedst til matematik

6) Stemningen i klassen er god

7) Hendes mand havde et værksted

8) De unge gik i biografen

9) Han trækker gardinet til side

10) Vi ligner hinanden ret meget

11) Vinduet vendte ud mod gaden

12) De sejlede med en husbåd

13) Kagen skal bages i ovnen

14) Båden sejler lidt over elleve

15) De vil hellere male selv

16) Kampen gik godt i begyndelsen

17) Han har passet sin træning

18) Forbruget af papir er stort

19) Det ringer ud til frikvarter

20) Hans bukser var meget korte

Practice list 1

1) Pigerne går rundt i haven

2) Hendes ansigt er stadig solbrændt

3) Filmen blev straks en succes

4) Jeg kan godt lide jazzmusik

5) Vi siger tillykke og skåler

6) Chaufføren ser ind i spejlet

7) Drys retten med hakket persille

8) De mørke pletter skyldes maling

9) Drengen stikker hånden langt frem

10) Han stiller mange svære spørgsmål

11) De fik jordbærkage til dessert

12) Hatten passer til min tøjstil

13) Natten bliver klar og kølig

14) Jeg glemmer aldrig den musik

15) Lad os bare køre igen

16) Jeg tager solbad på stranden

17) Gymnastik gør mig meget stærk

18) Du skal børste alle tænder

19) Nu blomstrer roserne på marken

20) Jeg var glad for bryllupsfesten

Practice list 2

1) Drengen blev medlem af klubben

2) Ikke langt væk ligger rådhuset

3) Flyttemænd har tit ømme muskler

4) Nu mangler vi blot tallerkner

5) Bogen var billig på udsalg

6) Cykler kan lejes mange steder

7) I spisestuen var lyset tændt

8) I går kom svalerne hertil

9) Jeg havde cyklet i solskin

10) Skoledrengen drikker et glas mælk

11) Suppen smagte godt af tomat

12) Vi spadserede en tur sammen

13) En ung pige kommer gående

14) Snart fylder rapporten ti sider 
15) Børnene og de voksne sover

16) En taxa kørte langsomt forbi

17) Kaninen sprang ud gennem hullet

18) Næste deltager var smedens søn

19) Lågen bag dem smækkede i

20) Under bogen ligger en tegning

Practice list 3

1) Han rensede skærmen for støv

2) Katten kom listende helt stille

3) Katten spinder $i$ hendes arme

4) Trøjen er syet af bomuld

5) Blomsterne vokser i små skåle

6) De to venner deler arbejdet
7) De sidder længe i tavshed

8) Store bølger slog mod stranden

9) Den gamle mand smilede stort

10) I regnbuen ses alle farver

11) De kørte direkte til skolen

12) Maden var rig på vitaminer

13) Konen er ældre end manden

14) Penge skal sættes i banken

15) Fødselsdagen er først på tirsdag

16) Postbudet har to små børnebørn

17) Det blev en pragtfuld ferie

18) Filmen var aldrig rigtig sjov

19) Jeg samler på gamle møbler

20) Om mandagen holder jeg fri 